\title{
Effect of Amlodipine and Captopril on Reproductive Capabilities of Male Laboratory Mice
}

\author{
Salma Saeed Abbas* \\ Department of Biology, College of Education for Pure Science, University of Basra, IRAQ.
}

\begin{abstract}
Background: Hypertension is well confirmed as a major risk factor for cardiovascular disease. Researches in the treatment of hypertension has produced a multitude of drug classes with different efficacy profiles, which including $\beta$-blockers, diuretics, ACE inhibitors, angiotensin receptor blockers and calcium channel blockers. This study aimed to investigate the effects of captopril and amlodipine on some of reproductive abilities. Materials and Methods: The laboratory mice were 10-12 weeks and 23-25 g divided into three groups, six mice of each one. Group A served as control group; injected with $0.1 \mathrm{ml}$ of normal saline, group B; injected with $0.1 \mathrm{ml}$ of Captopril with $0.2 \mathrm{mg} / \mathrm{kg}$, group C injected with $0.1 \mathrm{ml}$ of amlodipine $0.08 \mathrm{mg} /$ $\mathrm{kg}$. Results: Decrease in sperm count and testis weights and testosterone hormone of Amlodipine treated mice. While the numbers of sperms and testis weight of captopril treated mice were comparable to that of control
\end{abstract}

groups. But decrease normal sperms of captopril and Amlodipine treated mice comparable to that of control group. Conclusion: These results suggest that the treatment with amlodipine causes a significant testicular weight regression and reduction in sperm count.

Key words: Mice, Amlodipin, Captopril, Sex hormones, Sperms.

Correspondence

Dr. Salma Saeed Abbas,

Department of Biology, College of Education for Pure Science, University of Basra, IRAQ.

Phone no: +009647709064097

Email: salmaabbas300@gmail.com

DOI: 10.5330/ijpi.2019.2.15

\section{INTRODUCTION}

The blood is carried around the body in tubes called blood vessels. The pumping of the heart keeps blood moving through the blood vessels. Blood pressure is the force of blood pushing against blood vessel walls. It is measured in millimeters of mercury ( $\mathrm{mm} \mathrm{Hg}$ ). High blood pressure (HBP) means the pressure in your arteries is higher than it should be. Another name for high blood pressure is hypertension. ${ }^{1}$ Many blood pressure medications, known as antihypertensive, are available by prescription to lower high blood pressure (HBP or hypertension). ${ }^{2}$ As widely accepted, sperm counts may vary among different ejaculates according to several pathological conditions, lifestyle and exposure to pollutants. ${ }^{3}$ Several "acute" pharmacological treatments, as antibiotics, could cause subclinical and temporary reduction of male fertility; conversely, longterm medical treatment may severely affect male fertility, although this effect could be considered transient in most of the cases. Thus, nowadays, several long-term pharmacological treatments may represent a clinical challenge. To the best of our knowledge, association between several kind of antihypertensive drugs and reduction of male fertility has been showed in the mouse model. ${ }^{4,5}$

In particular, beta blockers and Calcium-channel Blockers (CCBs) seem to play a detrimental role on male fertility, causing in several cases azoospermia and/or oligozoospermia. In this regard, it was already demonstrated in the mouse model that CCBs, like amlodipine, can cause a reduction of testosterone, luteinizing hormone (LH) and follicular stimulating hormone (FSH), leading to affect spermatogenesis and sperm parameters. ${ }^{6,7}$ Calcium ions have a ubiquitous presence in somatic and germ cells. ${ }^{89}$ Calcium ions are, therefore, directly involved in the regulation of the following key processes that regulate or determine male fertility: blood testicular barrier, ${ }^{10,11}$ testosterone synthesis by Leydig cells, ${ }^{12}$ hormonal regulation of Sertoli cells function, ${ }^{13}$ secretion of products by Sertoli cells, ${ }^{7,8}$ capacitation of sperm cells, ${ }^{14}$ sperm motility, ${ }^{15}$ spermato- genesis, penetration of oocytes by sperm cells, prevention of polyspermy and gene expression. ${ }^{8,9}$ However, increased intrasperm concentration of calcium ions was determined to correlate negatively with sperm viability ${ }^{16}$ Captopril is a commonly used antihypertensive drug that acts by inhibiting the activity of angiotensin-converting enzyme ACE ${ }^{17}$ Moreover, a number of in vitro studies have confirmed the activity of ACE in semen. Captopril at $100 \mathrm{nmol} \mathrm{L-1}$ inhibits the ACE activity in cell culture of the rat cauda epididymis, which confirms the presence of ACE in these cells. ${ }^{18}$ Another in vitro study showed that ACE was localised in the periacrosomal area of ejaculated spermatozoa. ${ }^{19}$

\section{MATERIALS AND METHODS}

\section{The laboratory animals}

In the current study, the experimental animals were Mus musculus L. from Balb / C, which prepared from the Department of Pharmaceutical Control of Baghdad Governorate and raised in the Animal House of the Department of Life Sciences, College of Education for Pure Sciences, Basrah University under similar conditions, $20-25^{\circ} \mathrm{C}$ and a $12 \mathrm{hr}$ fixed lighting system $12 \mathrm{hr}$ light. ${ }^{20}$ The mice were placed in plastic cages of standard size $(30 \times 12 \times 11 \mathrm{~cm})$. The floor of the cages was sprayed with wood shavings, which are replaced weekly and the animals were fed in a specific diet. ${ }^{21}$ The laboratory mice were 10-12 weeks and 23-25 g divided into three groups, six mice of each one. Group A served as control group; injected with $0.1 \mathrm{ml}$ of normal saline, group B; injected with 0.1 $\mathrm{ml}$ of Captopril with a concentration of $0.2 \mathrm{mg} / \mathrm{kg}$, group C injected with $0.1 \mathrm{ml}$ of amlodipine $0.08 \mathrm{mg} / \mathrm{kg}$ concentration. 


\section{Serum preparation}

The blood serum was prepared by withdrawing the blood directly from the heart at Day 31. After treating the animals with chloroform, the tubes were placed in the centrifuge at a speed of 3,500 cycles per minute.

\section{Physiological tests}

Test of Captopril and amlodipine in the calculation of sperm count in laboratory mice: The method of vega et al..$^{22}$ was used in the calculation of the sperms. The right epididymis is taken from the mouse and cut by a blade and placed in a petri dish with Normal Saline.

Test of captopril and amlodipine effect on malformation of sperms: The Wyrobek and Bruce method, ${ }^{23}$ was used, where the sperm were taken from the left epididymis of the mouse and placed in a Petri dish of phosphate buffer saline and the sperms classified to normal sperm, malformed sperms.

Test of amlodipine and captopril effect on test is weight: According to weight of test is after fixated it with $10 \%$ formalin and then preserve it with $70 \%$ ethanol.

Effect of amlodipine and captopril in testosterone and luteinizing hormone: Method of kosasa ${ }^{24}$ was used in this test to estimate LH and also by method of kick lighter and Norman. ${ }^{25}$

\section{Statistical Analyses}

The statistical analysis are preformed using SPSS version 20 with $P<0.05$ at a significant. Data are expressed according to Mann-Whitney Test, Kruskal-Wallis Test and multivariate ANOVA.

\section{RESULTS}

\section{Effect of Captopril Amlodipine in the rate of sperms count and testis weight of the laboratory mice}

The results of the current study, as shown in Table 1, showed decrease in number of sperm and testis weights of Amlodipine treated mice. While the numbers of sperms and testis weight of captopril treated mice were comparable to that of control groups.

\section{Effect of Captopril and Amlodipine in the induction of laboratory mice sperms abnormalities}

The results of the statistical analysis shown in Table 2 and Figures 1-9 showed a significant decrease in the number of normal sperm and a significant increase in sperm abnormalities for both drugs and at a level of probability $(P<0.05)$ compared to control group.

\section{Effect of Captopril and Amlodipine in the level of} testosterone hormone and the Luteinizing hormone.

The current study indicated in Table 3 showed a significant decrease in the level of testosterone for mice treated with Amlodipine and a significant increase in the level of such hormone of mice that treated with Captopril compared with the control group at a level of probability $(p<0.05)$ compared to control group. The statistical analysis did not give any significant differences in the level of the luteinizing hormone of the groups (Captopril and Amlodipine).

\section{DISCUSSION}

Amlodipine is a long-acting calcium channel blocker (dihydropyridine class) used as an anti-hypertensive and in the treatment of angina. ${ }^{1}$ Like other calcium channel blockers, amlodipine acts by relaxing the smooth muscle in the arterial wall, decreasing peripheral resistance and hence reducing blood pressure; in angina it increases blood flow to the heart
Table 1: Effect of amlodipine and captopril in sperms count and testis weight of the laboratory mice.

\begin{tabular}{ccc}
\hline Treated groups & $\begin{array}{c}\text { Sperm count } \mathrm{mm}^{3} \\
\times 10^{6}\end{array}$ & Testis weight $(\mathrm{g})$ \\
\hline Control & $8.01+0.82$ & $0.0635+0.0072$ \\
Captopril $(0.2 \mathrm{mg} / \mathrm{kg})$ & $8.82+0.94$ & $0.0644+0.0055$ \\
amlodipine $(0.08 \mathrm{mg} / \mathrm{kg})$ & $5.75+0.12$ & $0.0496+0.0079$ \\
\hline
\end{tabular}

Table 2: Effect of Captopril and Amlodipine in the induction of laboratory mice sperm abnormalities.

\begin{tabular}{ccc}
\hline Treated groups & Normal sperms (\%) & Distorted sperms (\%) \\
\hline Control & $75+1.75$ & $25+1.57$ \\
Captopril $(0.2 \mathrm{mg} / \mathrm{kg})$ & $56+3.3^{*}$ & $44+3.38^{*}$ \\
Amlodipine $(0.08 \mathrm{mg} /$ & $64+0.178^{*}$ & $36+2.7^{*}$ \\
$\mathrm{~kg})$ & & \\
\hline
\end{tabular}

There were significant differences at the probability level $(P<0.05)$ compared with control group.

Table 3: Effect of amlodipine and captopril in testosterone level and luteinizing hormone.

\begin{tabular}{ccc}
\hline Treatment & $\begin{array}{c}\text { Testosterone } \mathrm{H} \\
(\mathrm{ng} / \mathrm{ml})\end{array}$ & $\begin{array}{c}\text { Luteinizing } \mathrm{H} \\
\text { IU/I }\end{array}$ \\
\hline Control & $4.41+1.75$ & $6.77+1.0$ \\
Captopril $(0.2 \mathrm{mg} / \mathrm{kg})$ & $5.44+0.4^{*}$ & $6.25+3.38$ \\
Amlodipine $(0.08 \mathrm{mg} / \mathrm{kg})$ & $2.45+0.6^{*}$ & $6.39+0.3$ \\
\hline
\end{tabular}

Presence of significant differences $(p \leq 0.05)$ in the level of testosterone hormone compared with the control group.

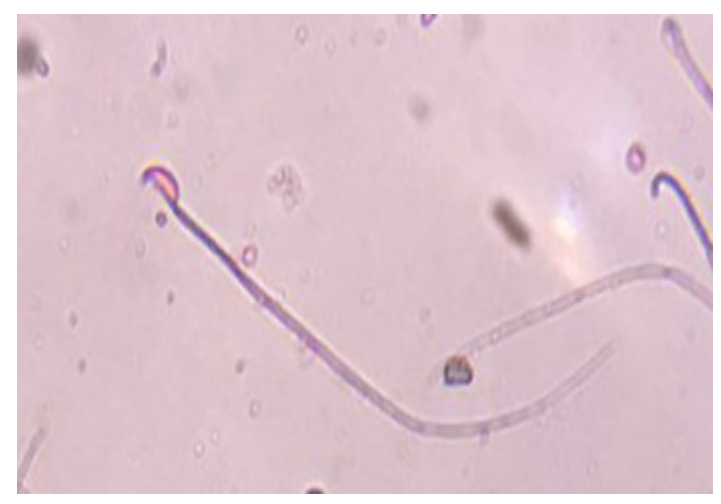

Figure 1: Normal sperm.

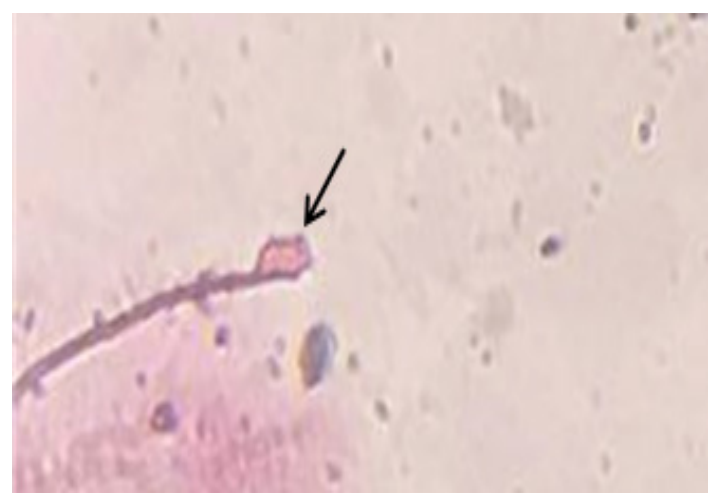

Figure 2: Abnormal head of sperm 


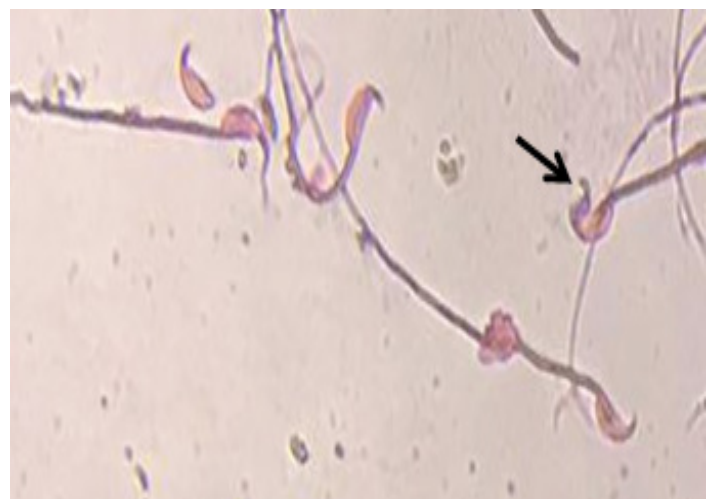

Figure 3: Abnormal sperm with distorted hook.

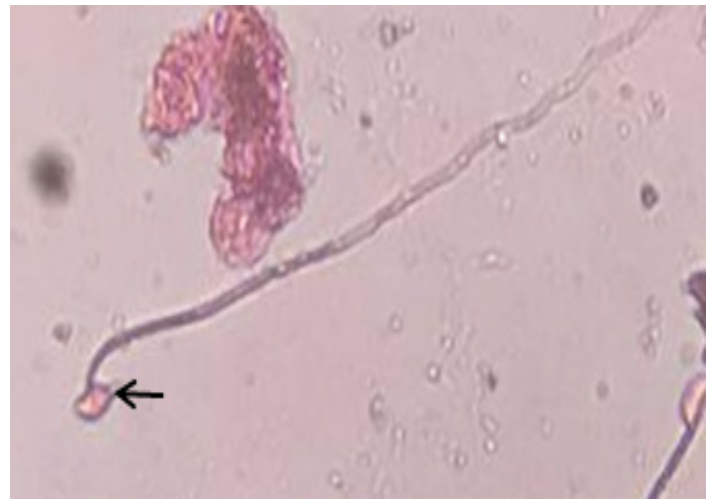

Figure 4: Abnormal sperm with spherical head

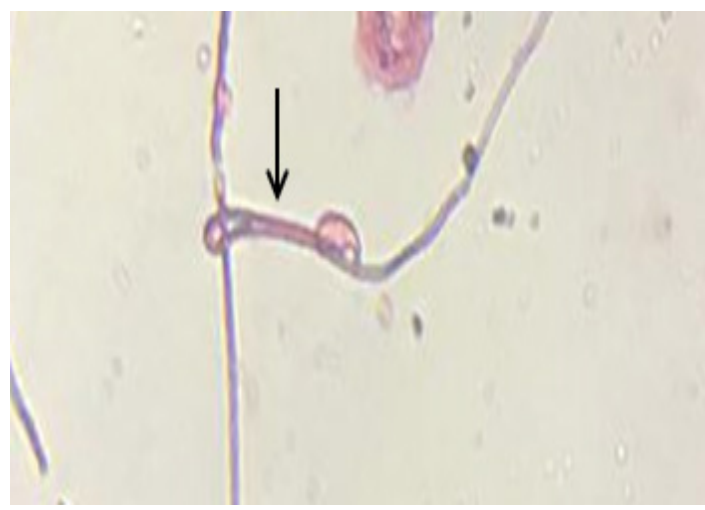

Figure 5: Abnormal sperm showing the coalescence of the medial segment

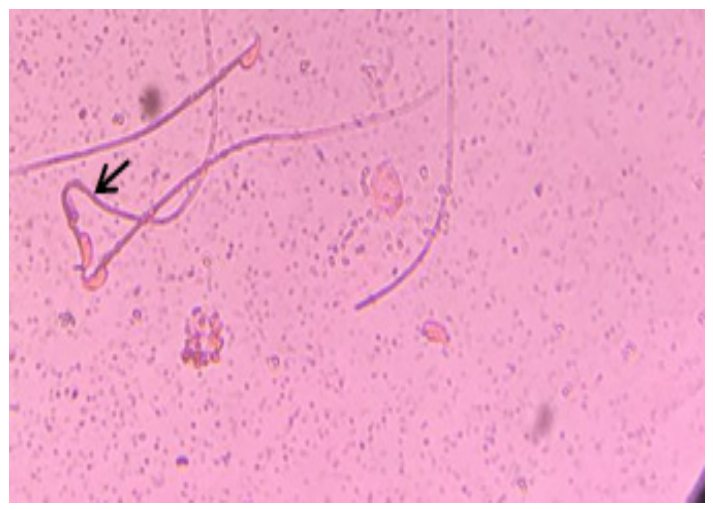

Figure 6: Abnormal sperm showing the curvature of medial segment

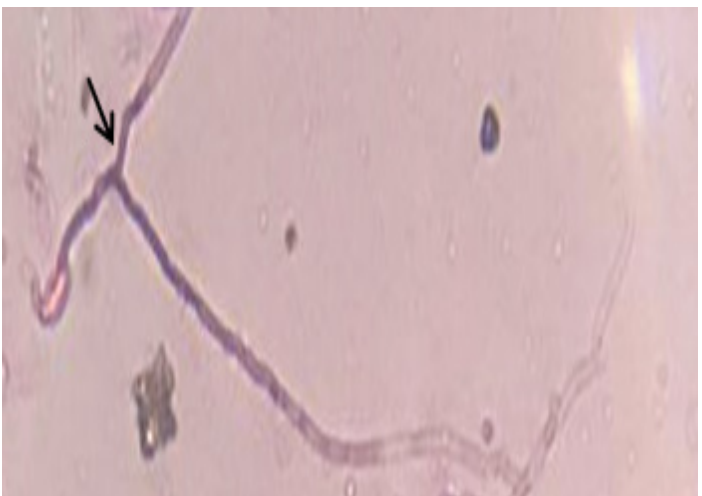

Figure 7: Abnormal sperm appears the tail splits

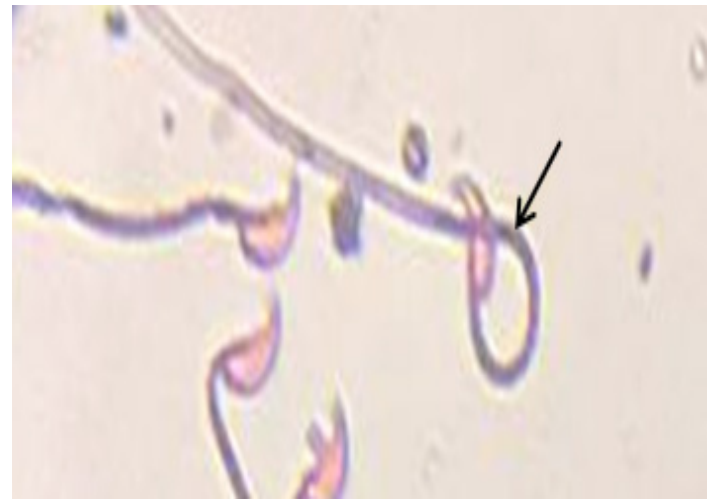

Figure 8: Abnormal sperm appears ball in middle segment

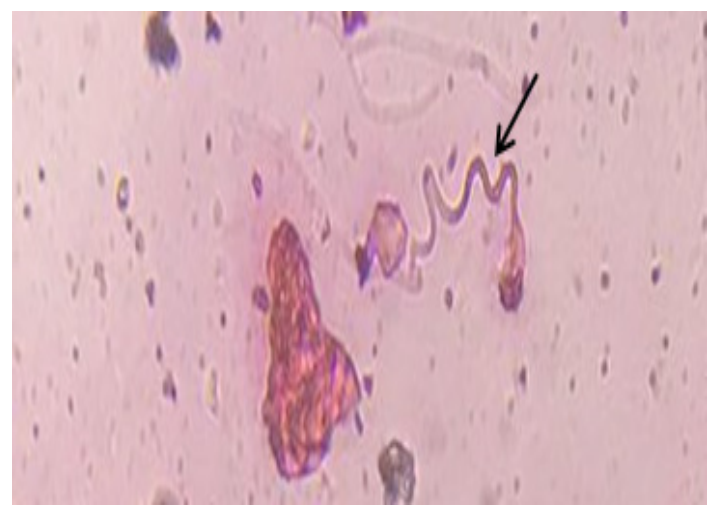

Figure 9: Abnormal sperm with distortion in middle part and tail

muscle, Amlodipine does also act as functional inhibitor of acid sphingomyelinase. ${ }^{2}$ While the Captopril is a commonly used antihypertensive drug. ${ }^{26}$ That acts by inhibiting the activity of angiotensin-converting enzyme (ACE). ${ }^{27}$ A zinc-containing metallopeptidase enzyme catalysing the conversion of angiotensin I into angiotensin II (a potent vasoconstrictor). ${ }^{28}$ Decreased angiotensin II synthesis reduces the activity of the renin angiotensin aldosterone system and hence the blood pressure as a result of vasodilation, which occurs in response to increased production of bradykinin and vasodilatory prostaglandins and decreased water and salt retention. ${ }^{29}$

Results of the current study showed a decrease in the weights of testis and the preparation of sperm and the level of hormone lipid testicular in the group of animals treated with amlodipine compared to the control group and this result is identical to the study of, ${ }^{30}$ who found that the 
drug Amlodipine cause a Decreased rats' testicular weights and were also identical to Oluwaseum's study, ${ }^{31}$ as there was a decrease in live sperm count for animals treated with amlodipine, while Captopril showed no effect on testis and sperms count.

The reason for the decrease in the level of testosterone hormone, normal sperm and the size and weight of the testicles may be attributed to the action of calcium channel blockers in the hypothalamic axis and changes in the hypothalamus released from the hypothalamus or the induced hormones of the pituitary gland which agreed with the results obtained by, ${ }^{32}$ if there is a decrease in the hormones that feed the fetus by the effect of calcium channel blockers, the decrease may be caused by stopping the process of the emergence of sperm in the test is due to the absorption of calcium ion in the testis. As a result, the sperm density decreases and its effect is blocked Calcium Suresh. Stopping the process of sperm formation supports the reduction in the weight of the testicle by the effect of the Cretaceous drug. At this stage, the conclusion is that the amlodipine causes a significant drop in testicular weight, sperm count and serum testosterone levels. While the Captopril effect on semen quality such as deformities but not quantity.

\section{CONCLUSION}

In conclusions, this study has shown that the amlodipine causes a significant drop in testicular weight, sperm count and serum testosterone levels. While the Captopril effect on semen quality such as deformities but not quantity.

\section{ACKNOWLEDGEMENT}

The authors gratefully acknowledge Dr. Waleed Majeed Al-Mayahi, for his extensive technical support.

\section{CONFLICT OF INTEREST}

The authors declare no conflict of interest

\section{ABBREVIATIONS}

ACE: Angiotensin-converting enzyme; CCBs: Calcium-channel Blockers; FSH: Follicular stimulating hormone; HBP: Hypertension; LH: Lluteinizing hormone.

\section{REFERENCES}

1. United States National Library of Medicine, National Institutes of Health. Drug Information Portal-Amlodipine. 2017

2. Kornhuber M, Trapp S, Pechmann S, et al. Identification of novel functional inhibitors of acid sphingomyelinase. PLoS One. 2011;6(8):e23852.

3. Nudell DM, Monoski MM, Lipshultz LI. Common medications and drugs: How they affect male fertility. Urol Clin North Am. 2002;29(4):965-73.

4. DaDantas S, Júnior E, DePalmieri SB, Rodrigues JOD, Caricati-Neto A, Jurkiewicz $\mathrm{A}$, Jurkiewicz $\mathrm{NH}$. Effects of clonidine in the isolated rat testicular capsule. Eur J Pharmacol. 2014;726:16-26.

5. Latif R, Lodhi GM, Aslam M. Effects of amlodipine on serum testosterone, testicular weight and gonado-somatic index in adult rats. J Ayub Med Coll Abbottabad. 2008;20(4):8-10.

6. Almeida SA, Teófilo JM, Anselmo FJA, Brentegani LG, Lamano-Carvalho TL. Antireproductive effect of the calcium channel blocker amlodipine in male rats. Exp Toxicol Pathol. 2000;52(4):353-6.

7. Latif R, Aslam M, Mehmood T. Spermatogenesis following discontinuation of calcium channel blocker amlodipine in rats. J Ayub Med Coll Abbottabad. 2009;21(1):25-7.

8. Latif R, Ghulam ML, Muhammad A. Effects of Amlodipine Besylate on serum testosterone, testicular weight and gonado-somatic index in adult rats. J Ayub Med Coll Abbottabad. 2008;20(4):8-10

9. Latif R, Aslam M, Mazhar HM, Idrees FB, Azhar M, Alia Z. Effects of Amlodipine Besylatebesylate on spermatogenesis in Sprague Dawley rats. Pak Armed Forces Med J. 2009;59(3):275-9.

10. Cheng CY, Mruk DD. Cell junction dynamics in the testis: Sertoli-germ cell inter actions and male contraceptive development. Physiol Rev. 2002;82(4):825-74.

11. Lui WY, Mruk D, Lee WM, Cheng CY. Sertoli cell tight junction dynamics: Their regulation during spermatogenesis. Biol Reprod. 2003;68(4):1087-97.

12. Latif R, Lodhi GM, Hameed W, Aslam M. Steroidogenesis in Amlodipine Besylate treated purified Leydig cells. Toxicol Appl Pharmacol. 2012;258(1):26-31.

13. Gorczyn'ska FE. The role of calcium in signal transduction processes in Sertoli cells. Reprod Biol. 2004;4(3):219-41.

14. Almeida SA, Teofilo JM, Anselmo F, Brentegani LG, Lamano CTL. Antireproductive effect of the calcium channel blocker Amlodipine Besylate in male rats. Exp Toxicol Pathol. 2000;52(4):353-6.

15. Guyton A, Hall J. Guyton and Hall Textbook of Medical Physiology. $12^{\text {th }}$ ed. Saunders, Elsevier Limited, USA. 2011;223-6.

16. Kumar N, Jain S, Gupta A, Tiwary AK. Spermicidal activity of sulfonylureas and meglitinide analogues: Role of intrasperm $\mathrm{Ca}^{2+}$ elevation. J Pharm Pharmacol. 2008;60(3):323-30.

17. Gouni-Berthold I, Berthold HK. Pharmacologic therapy for cardiovascular risk reduction in patients with the metabolic syndrome. Current Pharmaceutical Design. 2014;20(31):5025-38.

18. Wong PY, Uchendu CN. Studies on the renin-angiotensin system in primary monolayer cell cultures of the rat epididymis. The Journal of Endocrinology. 1991;131(2):287-93

19. Sabeur K, Vo AT, Ball BA. Characterization of angiotensin-converting enzyme in canine testis. Reproduction. 2001;122(1):139-46.

20. Al-Maliki SJ. A behavioral and some physiological effect of (apumgraveolens) seeds in albino mice. J Sci Bas. 2000;18(2):77-88.

21. Bell JM. Nutrient requirements of the laboratory mouse, In: Nutrient Requirements of Laboratory Animals. National Research Council-National Academy of Sciences.1962;39-49. Publ. 990.

22. Vega S, Guzman P, Garcia I, Espinosa J. Sperm shape abnormality and urine mutagenicity in mice treated with niclosamide. Mutant Res. 1988;204(2):269-76.

23. Wyrobek A, Bruce W. Chemical induction of sperm abnormalities. Proc Nat Acad Sci. 1975;72(11):4425-9.

24. Kosasa TS. Measurement of human Luteinizing Hormone. J Reprod Mid. 1981;26:201-6.

25. Kicklighter EJ, Norman RJ. The gonads. Clin Chem. 1989;43:658-60.

26. Zimmer J, Hawlitschek C, Rabald S, Hagendorff A, Zimmer HG, Rassler B. Effects of late-onset and long-term captopril and nifedipine treatment in aged spontaneously hypertensive rats: Echocardiographic studies. Hypertens Res. 2015;38(11):716-22.

27. Gouni-Berthold I, Berthold HK. Pharmacologic therapy for cardiovascular risk reduction in patients with the metabolic syndrome. Curr Pharm Des 2014;20(31):5025-38.

28. Yadav VR, Nayeem MA, Tilley SL, Mustafa SJ. Angiotensin II stimulation alters vasomotor response to adenosine in mouse mesenteric artery: Role for a and a adenosine receptors. Br J Pharmacol. 2015;172(20):4959-69.

29. Zisaki A, Miskovic L, Hatzimanikatis V. Antihypertensive drugs metabolism: An update to pharmacokinetic profiles and computational approaches. Curr Pharm Des. 2015;21(6):806-22.

30. Karthick S, Harisudha R. Histological and Histometric Study of Test is in Albino Rat Treated with Amlodipine. Int J Med Res Health Sci. 2014;3(2):241-4.

31. Oluwaseun HI, Bilikis I, Selimot HA, Jibril O. Toxicity Effects of Amlodipine on the Body Weight and Sperm Count in Adult Wistar Rats. AJCEM. 2013;1(1):1-4.

32. Bourguignon JP, Gerard A, Debougnoux G, Rose J, Franchimont P. Pulsatile release of $\mathrm{GnRH}$ from the rat hypothalamus in vitro: Calcium and glucose dependency and inhibition by superactive $\mathrm{GnRH}$ analogs. Endocrinology. 1987; 121(3):993-9. 